\title{
Assessing Inflammation in Acute Intracerebral Hemorrhage with PK11195 PET and Dynamic Contrast- Enhanced MRI
}

DOI:

10.1111/jon.12477

\section{Document Version}

Accepted author manuscript

Link to publication record in Manchester Research Explorer

Citation for published version (APA):

Abid, K. A., Sobowale, O. A., Parkes, L. M., Naish, J., Parker, G. J. M., du Plessis, D., Brough, D., Barrington, J., Allan, S. M., Hinz, R., \& Parry-Jones, A. R. (2018). Assessing Inflammation in Acute Intracerebral Hemorrhage with PK11195 PET and Dynamic Contrast-Enhanced MRI. Journal of Neuroimaging, 28(2), 158-161. https://doi.org/10.1111/jon.12477

Published in:

Journal of Neuroimaging

\section{Citing this paper}

Please note that where the full-text provided on Manchester Research Explorer is the Author Accepted Manuscript or Proof version this may differ from the final Published version. If citing, it is advised that you check and use the publisher's definitive version.

\section{General rights}

Copyright and moral rights for the publications made accessible in the Research Explorer are retained by the authors and/or other copyright owners and it is a condition of accessing publications that users recognise and abide by the legal requirements associated with these rights.

\section{Takedown policy}

If you believe that this document breaches copyright please refer to the University of Manchester's Takedown Procedures [http://man.ac.uk/04Y6Bo] or contact uml.scholarlycommunications@manchester.ac.uk providing relevant details, so we can investigate your claim.

\section{OPEN ACCESS}




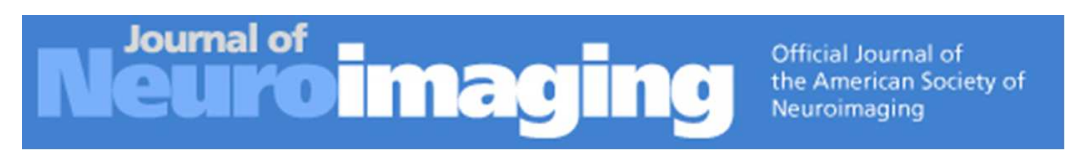

\section{Assessing inflammation in acute intracerebral hemorrhage with PK11195 PET and dynamic contrast-enhanced MRI}

\begin{tabular}{|c|c|}
\hline Journal: & Journal of Neuroimaging \\
\hline Manuscript ID & JON-17-5003.R1 \\
\hline Wiley - Manuscript type: & Short Communication \\
\hline Date Submitted by the Author: & 19-Sep-2017 \\
\hline Complete List of Authors: & $\begin{array}{l}\text { Abid, Kamran; University of Manchester, Division of Neuroscience and } \\
\text { Experimental Psyscology; Salford Royal Hospital , Greater Manchester } \\
\text { Neurosciences Centre } \\
\text { Sobowale, Oluwaseun; University of Manchester, Division of Neuroscience } \\
\text { and Experimental Psychology; Salford Royal Hospital , Greater Manchester } \\
\text { Neurosciences Centre } \\
\text { Parkes, Laura; University of Manchester, Division of Neuroscience and } \\
\text { Experimental Psychology } \\
\text { Naish, Josephine; University of Manchester Institute of Cardiovascular } \\
\text { Sciences } \\
\text { Parker, Geoff; University of Manchester, Division of Informatics, Imaging } \\
\text { and Data Sciences; Bioxydyn Limited, Rutherford House, Pencroft Way } \\
\text { Duplessis, Daniel; Salford Royal Hospital, Greater Manchester } \\
\text { Neurosciences Centre } \\
\text { Brough, Daniel; University of Manchester, Division of Neuroscience and } \\
\text { Experimental Psychology } \\
\text { Barrington, Jack; University of Manchester Institute of Cardiovascular } \\
\text { Sciences } \\
\text { Allan, Stuart; University of Manchester, Division of Neuroscience and } \\
\text { Experimental Psychology } \\
\text { Hinz, Rainer; The University of Manchester, Wolfson Molecular Imaging } \\
\text { Centre } \\
\text { Parry-Jones, Adrian; University of Manchester Institute of Cardiovascular } \\
\text { Sciences; Salford Royal Hospital, Greater Manchester Neurosciences } \\
\text { Centre }\end{array}$ \\
\hline Keywords: & $\begin{array}{l}\text { intracerebral haemorrhage, inflammation, blood-brain barrier, magnetic } \\
\text { resonance imaging, positron emission tomography }\end{array}$ \\
\hline Subject Area: & $\begin{array}{l}\text { Imaging Techniques < NEUROIMAGING, Magnetic Resonance Imaging } \\
\text { (MRI) < Magnetic Resonance (MR) < Imaging Techniques < } \\
\text { NEUROIMAGING, Positron Emission Tomography }(\mathrm{PET})<\text { Imaging } \\
\text { Techniques < NEUROIMAGING }\end{array}$ \\
\hline
\end{tabular}




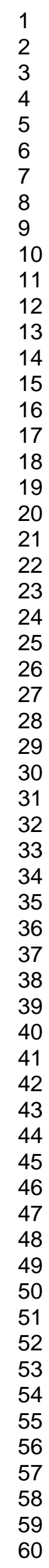

SCHOLARONE"

Manuscripts

7

21

23

24

26

27

29

30

32

33

34

35

36

37

38

41

42

43

45

46

47

48

49

50

52

53

54

56

57

58

60

American Society of Neuroimaging 


\section{Assessing inflammation in acute intracerebral hemorrhage with PK11195 PET and dynamic} $\underline{\text { contrast-enhanced MRI }}$

Imaging inflammation in acute intracerebral hemorrhage: a combined $\left.{ }^{11} \mathrm{C}\right](R)$ PK11195

PET and DCE MRI study

Kamran A Abid $\mathrm{PhD}^{1,3^{*}}$, Oluwaseun A Sobowale MRCS ${ }^{1,3^{*}}$, Laura M Parkes $\mathrm{PhD}^{1}$, Josephine Naish PhD ${ }^{1}$, Geoff JM Parker PhD ${ }^{1,2}$, Daniel du Plessis FRCPath ${ }^{3}$, David Brough $\mathrm{PhD}^{1}$, Jack Barrington $\mathrm{BSc}^{1}$, Stuart M Allan $\mathrm{PhD}^{1}$, Rainer Hinz $\mathrm{PhD}^{1}$, Adrian R Parry-Jones $\mathrm{PhD}^{1,3}$

${ }^{1}$ Faculty of Biology, Medicine and Health, The University of Manchester, Manchester, UK;

${ }^{2}$ Bioxydyn Limited, Manchester, UK; , Rutherford House, Pencroft Way, Manchester, M15 6SZ, UK;

${ }^{3}$ Greater Manchester Neurosciences Centre, Salford Royal NHS Foundation Trust, SalfordManchester, UK.

*Contributed equally

Corresponding Author:

Dr A.R. Parry-Jones

Salford Royal NHS Foundation Trust, Stott Lane

Salford, M6 8HD, UK

E-mail: adrian.parry-jones@manchester.ac.uk

Tel: +441612064458

Formatted: Default Paragraph Font, Font: (Default) +Body (Cambria), 11 pt, English

Fax: +441617076534

Running title: Multimodality imaging of brain inflammation in $\mathrm{ICH}$

Key words: Intracerebral haemorrhage, inflammation, blood-brain barrier, magnetic resonance imaging, positron emission tomography 


\section{Page 3 of 14}

1

2

3

4

5

6

7

8

9

10

11

12

14

15

16

17

18

19

20

21

22

23

24

25

26

27

28

29

30

31

32

33

34

35

36

37

38

39

40

41

42

43

44

45

46

47

48

49

50

51

52

53

54

55

56

57

58

59

60
Acknowledgements and $\div$ none

Disclosures: none.
Formatted: Line spacing: Double 


\begin{abstract}
Background and purpose:
\end{abstract}

Studies in animal models have suggestedsuggest that inflammation is a major contributor to secondary injury after intracerebral haemorrhage ( $\mathrm{ICH})$. Direct, non-invasive monitoring of inflammation in the human brain after ICH will facilitate early-phase development of antiinflammatory treatments. We sought to investigate the feasibility of multi-modality brain imaging in subacute ICH.

Methods:

Acute ICH patients were recruited to undergo multiparametric magnetic resenance imagingMRI (including dynamic contrast enhanced measurement of blood-brain barrier transfer constant $\left(K^{\text {trans }}\right)$ and positren emission tomegraphy $(\mathrm{PET})$ with $\left[{ }^{11} \mathrm{C}\right]-(R)-\mathrm{PK} 11195$. $\left[{ }^{11} \mathrm{C}\right]-(R)-\mathrm{PK} 11195$ binds to the translocator protein $18 \mathrm{kDa}$ (TSPO), which is rapidly upregulated in activated microglia. Circulating inflammatory markers were measured at the time of PET.

Results:

Five patients were recruited to this feasibility study with imaging performed-between 5 and 16 days after onset. Etiologies included hypertension-related small vessel disease ${ }_{2}$ cerebral amyloid angiopathy (CAA), cavernoma and arteriovenous malformation $(\mathrm{AVM}) .\left[{ }^{11} \mathrm{C}\right]-(R)-$ PK11195 binding was low in all hematomas and two (patient 2 (probable CAA) and patient 4 $(\mathrm{AVM}))$ showed widespread increase in binding in the perihematomal region vs. contralateral. All had increased $K^{\text {trans }}$ in the perihematomal region (mean difference $=2.2 \mathrm{x}$ $10^{-3} \mathrm{~min}^{-1} ; \mathrm{SD}=1.6 \times 10^{-3} \mathrm{~min}^{-1}$ ) vs. contralateral. Two cases_(patients 1 (cavernoma) and 4 
$\underline{(\mathrm{AVM}))}$ had delayed surgery (three and 12-months post-onset, respectively) with biopsies showing intense microglial activation in perilesional tissue.

Conclusions:

Our study demonstrates for the first time the feasibility of performing complex multimodality brain imaging for non-invasive monitoring of neuroinflammation for this severe stroke subtype. These techniques will be useful tools in developing anti-inflammatory treatments for clinical $\mathrm{ICH}$. 
Introduction

\begin{abstract}
After intracerebral hemorrhage (ICH), extravasation of blood leads to immediate physical tissue injury. Secondary damage ensues over hours and days, mediated by a cascade of molecular and cellular events involving the toxic effects of blood components and sterile inflammation. ${ }^{1}[1]$. Within hours of onset, microglia become activated taking on a proinflammatory phenotype, releasing cytokines and chemokines that activate astrocytes and endothelial cells causing blood-brain barrier (BBB) breakdown (alongside the direct effects of the ICH), recruitment of circulating leukocytes, and exacerbation of perihematomal edema. $^{2}[2]$. Previous clinical studies in ICH have largely focused on peripheral inflammatory markers showing associations between fever, elevated white blood cell count, interleukin-6 (IL-6), C-reactive protein (CRP), and fibrinogen on admission and worse sub-acute and longterm outcomes. ${ }^{3}[3]$. These clinical studies demonstrate the importance of the systemic inflammatory response, but provide no information on processes within the brain, where inflammation contributes directly to secondary injury. Given the growing interest in modulating inflammation in acute $\mathrm{ICH}$ and the failure in ischemic stroke to translate findings from animal models, a means of studying inflammation in the intact human brain after ICH is urgently required.
\end{abstract}

Using advanced multimodality imaging, it is possible to estimate the extent and distribution of microglial activation and BBB breakdown. When activated, microglia express the translocator protein $18 \mathrm{kDa}$ (TSPO), normally present at very low levels in the central nervous system. $\left[{ }^{11} \mathrm{C}\right]-(R)-\mathrm{PK} 11195$ binds to TSPO and has been used for pesitren emission tomography (PET) studies of acute ischemic stroke ${ }_{2}^{4}[4]$, but in vivo imaging of microglial activation in ICH has not been previously described. Using magnetic resonance imaging (MRI) and computed tomography (CT) dynamic contrast enhanced (DCE) techniques, two previous studies have quantified $\mathrm{BBB}$ breakdown after $\mathrm{ICH}^{5,6}[5,6]$. Combining this 


\section{Methods}

Patients between 4 and 28 days after onset of acute, spontaneous ICH were recruited from Salford Royal NHS Foundation Trust (Salford, UK) between 05/12/12 and 28/03/2014, following appropriate approvals. We excluded patients if they had a contraindication to MRI, were pregnant or breast feeding, had significant renal impairment, had an acute neurosurgical procedure performed or planned or who were taking medications which were likely to interfere with $\left[{ }^{11} \mathrm{C}\right]-(R)-\mathrm{PK} 11195$ binding. MRI was performed on a Philips $3 \mathrm{~T}$ Achieva scanner (Salford Royal Hospital) with an 8 channel head coil. PET scans were performed within 4 days of MRI on a High Resolution Research Tomograph (Siemens/CTI) PET scanner (Wolfson Molecular Imaging Centre, University of Manchester). Venous blood was collected at recruitment (where possible) and immediately prior to the PET scan for measurement of key inflammatory mediators (CRP, IL-6, interleukin-1 (IL-1); see online supplement for immunoassay methods).

MRI included $T_{1}$-weighted volumetric Fast Field Echo ( $T_{1}$-FFE) imaging, $T_{2}$-weighted fluid attenuated inversion recovery (FLAIR) imaging and $\mathrm{T}_{1}$-weighted DCE-MRI. Parametric maps of the blood-brain barrier transfer constant $\left(K^{\text {trans }}\right)$ were generated from DCE-MRI data using an uptake model (details of MRI acquisition and analysis in online supplementary 
methods). PET data were analyzed as previously described. ${ }^{7}[7]$. In brief, iterative ordered subset expectation maximization 3D method was used to reconstruct a quantitative series of dynamic images from the $60 \mathrm{~min}$ PET emission scan. A reference tissue input function was extracted from cerebellar grey matter in order to generate parametric maps of binding potential $\mathrm{BP}_{\mathrm{ND}}$ using the simplified reference tissue model. Using SPM (version 8), all maps and images were co-registered to the $\mathrm{T}_{1}$-weighted volume $\mathrm{MRI}$. The $\mathrm{T}_{1}$-weighted volume image was segmented into grey matter and white matter probability maps and a maximum probability brain atlas ${ }^{\underline{8}}[8]$ was warped in to individual space. Two regions of interest (ROI) were defined manually from the $\mathrm{T}_{1}$-weighted and FLAIR images, representing hematoma and perihematomal edema. Corresponding ROIs in the contralateral brain region were generated by flipping the ipsilateral ROIs about the midline in the axial plane excluding any non-brain tissue. The mean binding potential $\left(\mathrm{BP}_{\mathrm{ND}}\right)$ of $\left[{ }^{11} \mathrm{C}\right]-(R)-\mathrm{PK} 11195$ and $K^{\mathrm{trans}}$ within each ROI was then extracted from the parametric maps using Analyze version 12.0 (Mayo Clinic).

Results

Five patients with acute ICH underwent research brain imaging between 5 and 25 days after onset as part of this feasibility study (Table 1). All patients tolerated the scans without difficulty except patient 3 , who was unable to complete the last $22 \mathrm{~min}$ of the $60 \mathrm{~min}$ emission PET scan and was the only one to undergo both scans on one day. Etiologies confirmed using appropriate clinical imaging included a cavernous angioma, an arteriovenous malformation (Figure 1), probable cerebral amyloid angiopathy and small vessel disease due to chronic hypertension. $\left[{ }^{11} \mathrm{C}\right]-(R)-\mathrm{PK} 11195$ binding was low in all hematomas. Patients 2 \& 4 showed increased $\left[{ }^{11} \mathrm{C}\right]-(R)-\mathrm{PK} 11195$ binding both within the perihematomal edema volume $(0.24$ and 0.06 respectively, vs. contralateral $)$ and the ipsilateral brain region $(\theta .13 \&$ 
$\theta .12$ respectively, vs. contralateral; Figure 2). Patients 1 and 4 underwent surgery at 3 and 12 months, respectively, with perlesional tissue demonstrating intense microglial activation. Analyses of DCE-MRI data show increases in $K^{\text {trans }}$ in the perihematomal edema volume (mean difference $=2.2 \times 10^{-3} \mathrm{~min}^{-1} ; \mathrm{SD}=1.6 \times 10^{-3} \mathrm{~min}^{-1}$ ) in all 5 patients relative to the contralateral. Visual inspection of images (Figure 2) consistently demonstrates a clear ring of increased $K^{\text {trans }}$ adjacent to the outer border of the hematoma. No pattern is suggested for a relationship between circulating inflammatory markers and imaging., though for all cases, ERP was lower at the time of PET seanning than at recruitment.

\section{Discussion}

Our small study is the first to show imaging of microglial activation with PET after ICH and demonstrates the feasibility of performing complex multimodality brain imaging after acute ICH. However, we found that performing PET and MR scans on different days may improve successful study completion. All patients show clear ring-shaped BBB breakdown in the outer border of the hematoma, suggesting that delivery of treatments with limited transfer across the intact BBB may be enhanced in acute ICH. We observed a heterogeneous pattern of $\left[{ }^{11} \mathrm{C}\right]-(R)-\mathrm{PK} 11195$ binding, with only two patients demonstrating enhanced binding around the hematoma. In neither case was the binding closely co-located with the BBB disruption, suggesting that factors other than microglial activation may drive BBB breakdown after ICH, an observation that should be investigated further in future studies. Late perilesional biopsies in two patients did show intense microglial activation, but only one had enhanced $\left[{ }^{11} \mathrm{C}\right]-(R)-\mathrm{PK} 11195$ binding acutely. The long delay between PET and biopsies makes it difficult to interpret this disparity.

Summary/Conclusions 
We have demonstrated the feasibility of performing complex multimodality imaging to track the inflammatory response after ICH. This will be a vital tool in investigating this promising therapeutic target with potential use in early phase proof-of-concept clinical trials.

References

[1] Gong C, Hoff JT, Keep RF. Acute inflammatory reaction following experimental intracerebral hemorrhage in rat. Brain Research. 2000;871:57-65.

[2] Askenase MH, Sansing LH. Stages of the ifnflammatory rResponse in pPathology and tTissue rRepair after ifntracerebral hHemorrhage. Seminars in Neurology 2016;36:288-97. [3] Di Napoli M, Godoy DA, Campi V, et a, Masotti L, Smith CJ, Jones ARP, Hopkins SJ, Slevin M, Papa F, Mogoanta L, Pirici D, Wagner AP1. C- C-reactive protein in intracerebral hemorrhage Time course, tissue localization, and prognosis. Neurology- 2012;79:690-9. [4] Gerhard A, Schwarz J, Myers R, Wise R, Banati RB. Evolution of microglial activation in patients after ischemic stroke: a C-11 (R)-PK1195 PET study. Neuroimage2005;24:591-5.

[5] McCourt R, Gould B, Kate M, et aAsdaghi N, Kosior JC, Coutts S, Hill MD, Demchuk A, Jeerakathil T, Emery D, Butcher KS.1. Blood-bBain b-Barrier c-Compromise

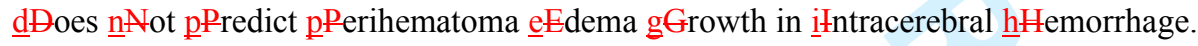
Stroke- 2015;46:954-60. [6] Aksoy D, Bammer R, Mlynash M, et al. Venkatasubramanian C, Eyngorn I, Snider RW, Gupta SN, Narayana R, Fischbein N, Wijman CAC.Magnetic r.Resonance itmaging pProfile of $\underline{b} B$ lood- $\underline{b} B$ rain $\underline{b} B$ Barrier $\underline{i}$ Injury in pPatients $\underline{w} W i t h \underline{a} A$ cute ifntracerebral hHemorrhage. Jeurnal of the American Heart Association. 2013;2:e00161.

[7] Su ZJ, Herholz K, Gerhard A, et alRoncaroli F, Du Plessis D, Jackson A, Turkheimer F, Hinz R. C-11 -(R)PK11 195 tracer kinetics in the brain of glioma patients and a comparison of two referencing approaches. Eurepean Jeurnal of Nuclear Medicine and Molecular Imaging. 2013;40:1406-19.

[8] Hammers A, Chen CH, Lemieux L, et alAllom R, Vossos S, Free SL, Myers $R$, Brooks DJ, Duncan JS, Koepp MY.: Statistical neuroanatomy of the human inferior frontal gyrus and probabilistic atlas in a standard stereotaxic space. Human Brain Mapping. 2007;28:34-48.

\begin{tabular}{|c|}
\hline $\begin{array}{l}\text { Formatted: } \\
\text { Roman, } 12\end{array}$ \\
\hline Field Code \\
\hline $\begin{array}{l}\text { Formatted: } \\
\text { Roman, } 12\end{array}$ \\
\hline $\begin{array}{l}\text { Formatted: } \\
\text { Roman, } 12\end{array}$ \\
\hline $\begin{array}{l}\text { Formatted: } \\
\text { Roman, } 12\end{array}$ \\
\hline $\begin{array}{l}\text { Formatted: } \\
\text { Roman, } 12\end{array}$ \\
\hline $\begin{array}{l}\text { Formatted: } \\
\text { Roman, } 12\end{array}$ \\
\hline $\begin{array}{l}\text { Formatted: } \\
\text { Roman, } 12\end{array}$ \\
\hline $\begin{array}{l}\text { Formatted: } \\
\text { Roman, } 12\end{array}$ \\
\hline $\begin{array}{l}\text { Formatted: } \\
\text { Roman, } 12\end{array}$ \\
\hline $\begin{array}{l}\text { Formatted: } \\
\text { Roman, } 12\end{array}$ \\
\hline $\begin{array}{l}\text { Formatted: } \\
\text { Roman, } 12\end{array}$ \\
\hline $\begin{array}{l}\text { Formatted: } \\
\text { Roman, } 12\end{array}$ \\
\hline $\begin{array}{l}\text { Formatted: } \\
\text { Roman, } 12\end{array}$ \\
\hline $\begin{array}{l}\text { Formatted: } \\
\text { Roman, } 12\end{array}$ \\
\hline $\begin{array}{l}\text { Formatted: } \\
\text { Roman, } 12\end{array}$ \\
\hline $\begin{array}{l}\text { Formatted: } \\
\text { Roman, } 12\end{array}$ \\
\hline $\begin{array}{l}\text { Formatted: } \\
\text { Roman, } 12\end{array}$ \\
\hline $\begin{array}{l}\text { Formatted: } \\
\text { Roman, } 12\end{array}$ \\
\hline $\begin{array}{l}\text { Formatted: } \\
\text { Roman, } 12\end{array}$ \\
\hline $\begin{array}{l}\text { Formatted: } \\
\text { Roman, } 12\end{array}$ \\
\hline $\begin{array}{l}\text { Formatted: } \\
\text { Roman, } 12\end{array}$ \\
\hline $\begin{array}{l}\text { Formatted: } \\
\text { Roman, } 12\end{array}$ \\
\hline Formatted \\
\hline Formatted \\
\hline Formatted \\
\hline Formatted \\
\hline Formatted \\
\hline Formatted \\
\hline Formatted \\
\hline
\end{tabular}


Table 1. Baseline characteristics, inflammatory markers and imaging data.

\section{Baseline Characteristics}

\section{Patient 1}

\section{Patient 2}

Patient 3

\section{Patient 4}

(n)

Age (years)

Sex

GCS at presentation

$\mathrm{ICH}$ etilology

ICH location

30

Female

14

Cavernous

angioma $^{2}$

Right temporal

$\mathrm{ICH}$ volume (ml)

PHE volume (ml)

PET scan (days post-onset)

MR scan (days post-onset)

Inflammatory mediators

IL-1 $\beta$

baseline $(\mathrm{pg} / \mathrm{ml})$

PET scan $(\mathrm{pg} / \mathrm{ml})$

IL-6

baseline $(\mathrm{pg} / \mathrm{ml})$

PET scan $(\mathrm{pg} / \mathrm{ml})$

IL-8

baseline $(\mathrm{pg} / \mathrm{ml})$

PET scan $(\mathrm{pg} / \mathrm{ml})$

CRP

baseline $(\mathrm{mg} / \mathrm{l})$

PET scan (mg/l)

DCE-MRI parameters

Mean $K^{\text {trans }}\left(\right.$ x $\left.10^{-3} \mathrm{~min}^{-1}\right)$

Perihematomal edema

\begin{tabular}{llllll} 
Ipsilateral & 1.8 & 5.7 & 2.1 & 2.9 & 2.2 \\
Contralateral & 0.4 & 0.7 & 1.0 & 1.0 & 0.6 \\
Ipsilateral - contralateral & 1.4 & 5.0 & 1.0 & 1.9 & 1.6 \\
\hline
\end{tabular}

$\begin{array}{ccccc}6.1 & 6.7 & 8.5 & 30.0 & 7.1 \\ 4.3 & 6.9 & 5.2 & 15.9 & 4.4 \\ 7 & 11 & 25 & 16 & 10 \\ 9 & 10 & 25 & 12 & 7\end{array}$

10

7

$\begin{array}{ccccc}- & - & 0.56 & 0.63 & 0.81 \\ 0.81 & 1.07 & 1.90 & 1.94 & 2.01 \\ & & & & \\ - & - & 7.77 & 2.35 & 2.73 \\ 3.82 & <0.012 & 4.29 & 1.5 & 4.47\end{array}$

$\begin{array}{lllll}- & - & 16.97 & 16.12 & 35.16\end{array}$

$\begin{array}{lllll}11.53 & 4.84 & 15.77 & 10.66 & 25.59\end{array}$

$\begin{array}{ccccc}- & - & 2.80 & 4.32 & 4.54 \\ 0.472 & 0.598 & 0.862 & 0.85 & 1.64\end{array}$

Formatted: Font: Bold, Underline Formatted: Font: Bold, Underline

Formatted: Underline

Formatted: Font: Bold, Font color:

Background 1

Formatted Table

Table 1: Baseline characteristies, inflammatory markers and imaging data. ${ }^{1}$ Based on modified Boston criteria; ${ }^{2}$ Confirmed on histology at later surgical resection. $\mathrm{ICH}=$ intracerebral haemorrhage, $\mathrm{pg}=$ picogram, $\mathrm{ml}=$ millilitre, $1=$ itre, $\mathrm{mg}=$ milligram, $\mathrm{GCS}=$ 


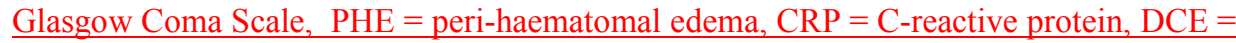

dynamic contrast-enhanced, $K^{\text {trans }}=$ volume transfer constant, IL $=$ interleukin, CAA $=$ cerebral amyloid angiopathy.

Figure legends

Figure 1: Cluster of differentiation 68CD68 immunostaining (original magnification x400) demonstrates diffuse microglial activation (2a) in patient 1 (suspected cavernoma) and activated microglia and phagocytic activity $(2 \mathrm{~b})$ in patient 4 (arteriovenous

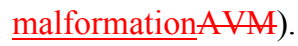

Figure 2: Representative parametric maps of $\left[{ }^{11} \mathrm{C}\right]-(R)-\mathrm{PK} 11195$ PET binding potential $\left(\mathrm{BP}_{\mathrm{ND}}\right)$ (superimposed on to $\mathrm{T}_{1}$-weighted images) and volume transfer constant $\left(K^{\text {trans }}-2\right.$ with Fluid-attenuated inversion recovery (FLAIR) FLAIR images from each patient with regions of interestROIs for hematoma (green) and edema (red). Increased $\left[{ }^{11} \mathrm{C}\right]-(R)-\mathrm{PK} 11195$ binding Roman, $12 \mathrm{pt}$ is indicated in patients $2 \& 4$ by arrows. 


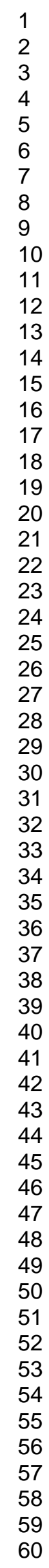




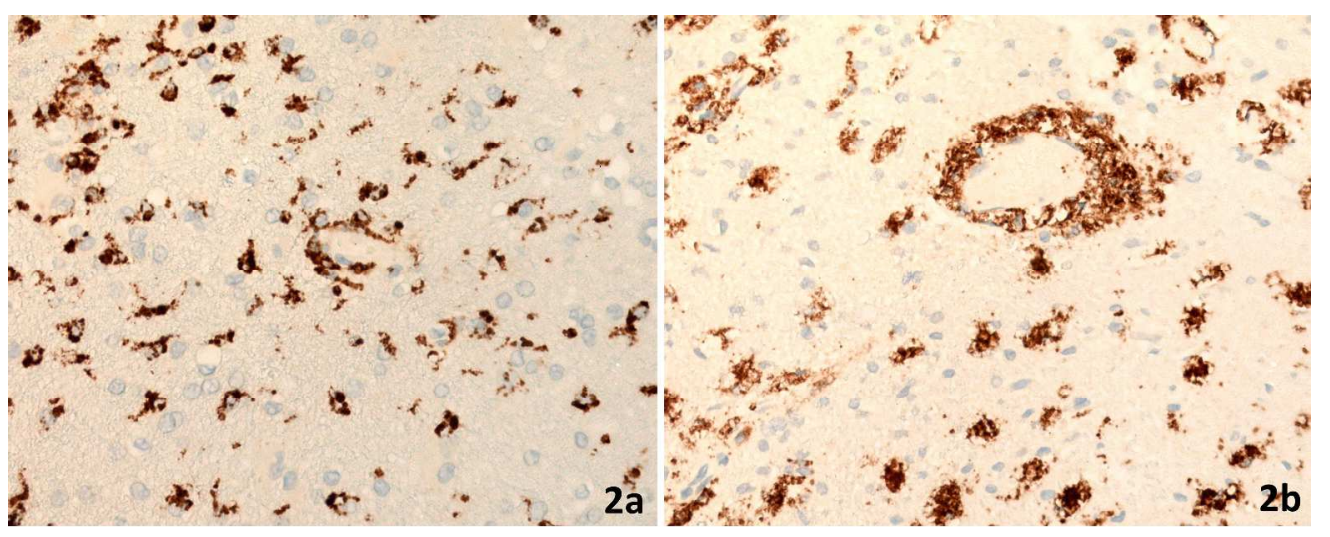

Cluster of differentiation 68 immunostaining (original magnification $\times 400$ ) demonstrates diffuse microglial activation (2a) in patient 1 (suspected cavernoma) and activated microglia and phagocytic activity (2b) in patient 4 (arteriovenous malformation).

$1278 \times 503 \mathrm{~mm}(96 \times 96$ DPI) 


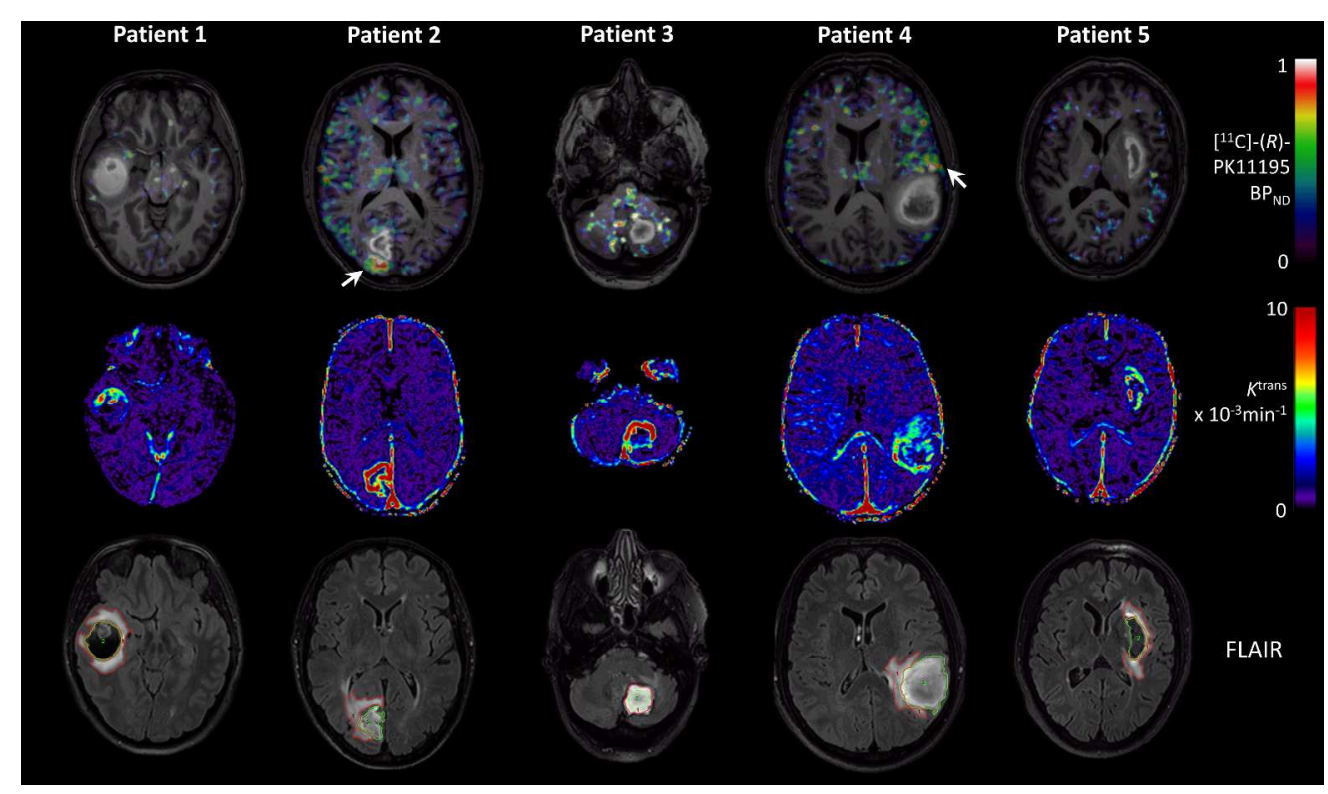

Representative parametric maps of [11C]-(R)-PK11195 PET binding potential (BPND) (superimposed on to T1-weighted images) and volume transfer constant (Ktrans) with Fluid-attenuated inversion recovery (FLAIR) images from each patient with regions of interest for hematoma (green) and edema (red). Increased [11C]-(R)-PK11195 binding is indicated in patients $2 \& 4$ by arrows.

$1280 \times 750 \mathrm{~mm}(96 \times 96$ DPI $)$ 